\title{
Research on the Basic Function Orientation and Development Strategy of the Social Science Association of Colleges and Universities in the New Era
}

\author{
Taking the Social Science Association of N University as an Example
}

\author{
Wei Kong \\ School of Economics \\ Nanjing University of Finance and Economics \\ Nanjing, China
}

\begin{abstract}
In recent years, colleges and universities all over China have set up social science associations, which has become an important form of organization in colleges and universities. On the basis of combing the development history and current situation of all kinds of social science associations in China, especially in colleges and universities, and combined with the existing exploration of the function orientation of the social science associations in colleges and universities, this paper summarizes the basic function orientation and management organization form of the social science associations in colleges and universities in the new era. Finally, taking $\mathbf{N}$ University as a case, it puts forward the development strategy of "borrow, dislocation and substitution".
\end{abstract}

Keywords-social science associations in colleges and universities; function orientation; development strategy

\section{INTRODUCTION}

Since Guangxi Normal University set up the first College Social Science Association in 1991, colleges and universities social science associations have been gradually established in all provinces of China, and dozens of colleges and universities social science associations have been established in Guangxi, Sichuan, Shandong, Hainan, Anhui and other places, displaying the trend of all flowers booming together and vigorous development. The first social science association of Jiangsu Province was founded in April 2015. In the following more than a year, more than 20 colleges and universities in Jiangsu Province have established the association of social science. On December 24, 2015, the establishment of the Social Science Association of $\mathrm{N}$ University marks the construction of philosophy and social science of the university has entered a new development stage, especially the substantial changes have taken place in the breadth and depth of communication with the social science circle of the province.

In facing with the new era, the report of the 19th National Congress of the Communist Party of China emphasizes that, "accelerating the construction of philosophy and social science with Chinese characteristics". This important exposition has blown the clarion call for the development of philosophy and social science under the historical background of socialism with Chinese characteristics entering a new era. Therefore, how to further define the basic function of the university social science association and formulate the development strategy for philosophy and social science in the new era has become an important issue that should be considered in depth for the university social science associations.

On the basis of combing the development history and current situation of all kinds of social science associations in China, especially in colleges and universities, and combined with the existing exploration of the function orientation of the social science associations in colleges and universities, this paper summarizes the basic function orientation and management organization form of the social science associations in colleges and universities in the new era, and puts forward the development strategy taking $\mathrm{N}$ University as a case. In summary, after a brief review of the development of the social science associations in the colleges and universities in China, this paper is divided into the following parts: first, it is the development history of the social science association and the exploration of its basic function orientation; second, it is the organization and management of the of social science associations in colleges and universities under the existing organizational system environment; third, it is the management form and development strategy of $\mathrm{N}$ University social science association; fourth, it is conclusion.

\section{THE DEVELOPMENT History AND FUNCTION ORIENTATION OF THE SOCIAL SCIENCE ASSOCIATION IN COLLEGES AND UNIVERSITIES}

After the Third Plenary Session of the 11th CPC Central Committee, all kinds of associations have been established, 
and colleges and universities have gradually set up their own associations after putting things out of order, which is the "golden age" for the development of social science associations. At that time, under the environment of planning system, the government was able to give the association relatively abundant financial support, and carried out flourishing activities, and thus the function of the associations were duly displayed. Since the 1990s, with the deepening of economic and political reform, the ecological environment of the society has changed significantly that all kinds of societies have returned from the appurtenances of government institutions to the truly independent, autonomous and non-profit civil organizations. The development of the society was facing serious challenges. Some social science associations have the problems of low status, no obvious role, weak social identity and insufficient development funds. The enthusiasm of the members of the associations has declined, and the work difficulty has increased obviously. However, the associations in colleges and universities have the advantages of talents and funds, so their work can be carried out smoothly. On the other hand, because a large number of resources were separated from the administrative control and enter the society and market, which widens the demand space for the survival, development and function of the associations in colleges and universities, so these associations have obtained the opportunity for further development.

Since the beginning of the new century, especially the promulgation of some programmatic documents, such as "Opinions on Further Developing and Prospering the Philosophy and Social Science in Colleges and Universities" issued by the Ministry of Education and "Opinions on Further Prospering the Philosophy and Social Science" issued by the Central Committee of the Communist Party of China, clarified the important position of colleges and universities in developing and prospering the philosophy and social sciences in China, which have received unprecedented development opportunities and space. Based on the prosperity and development of the society organizations, some colleges and universities have established the social science associations.

In recent years, relying on the resources and development opportunities of the universities, the social science associations have gradually grown up and become a group of active associations in social science societies. However, since the associations of social science in colleges and universities are the academic mass organization and do not have the power of institutional management given by the university management system, the academic management activities are restricted by the university management system, and its academic management function has been weakened, and the association of social science in colleges and universities itself has not formed an accurate functional orientation, so it is difficult to effectively play the role as the academic platform.

With the practice of the of social science associations in colleges and universities, people have made a preliminary theoretical discussion on the development of the association from the aspects of organizational nature, functional connotation and basic positioning.

\section{A. Analyzing the Organizational Nature of the Social Science Association of Colleges and Universities from Its Connotation and Extension}

As an academic mass organization of social science under the leadership of the Party Committee of the university, the social science associations is the leader and manager of all kinds of social science associations in the university, the organizer and promoter to realize the transformation of research results of social sciences in the university and guide social sciences workers to serve the society, with the comprehensive advantages of "think tank". As the bridge and link between the party and authority of the university and the philosophy and social sciences workers, the social science association of colleges and universities undertakes the important task of organizing the philosophy and social sciences workers to strengthen the construction of the university's spiritual civilization, providing spiritual power, intellectual support and ideological guarantee for the personnel training, and creating a good public opinion environment in the campus.

\section{B. Illustrating the Function and Connotation of the Social Science Associations from Three Aspects of University, Government and Society}

Peng Zhengwen (2008) pointed out that mass organizations, including the association of social science of colleges and universities, should be based on colleges and universities, play the role of academic management, and improve the overall level of colleges and universities; serve the government, and strive to become a think tank and "brain" of the party and the government in the scientific decision-making; strive to undertake the social functions that are responsible for, and effectively expand the living and development space of the association of social science of colleges and universities.

\section{Discussing the Basic Position of the Social Science Association in Colleges and Universities from the Requirements of the Development of the Party and the Country}

As the joint organization of philosophy and social sciences workers inside and outside universities under the leadership of the Communist Party of China, the association of social science in universities must accurately grasp the new tasks and requirements put forward by the development of the party and the country for the work of philosophy and social sciences, and make clear the four basic positions, that are the important forces and positions of learning, researching, propagating Marxism, the main force and vanguard of the prosperity and development of philosophy and social sciences, a think base and think tank that "can be trusted, used, relied on and inseparable", and the "home of social scientists" to unite, guide and serve philosophy and social science workers. (Li Ning, 2014). 
discussion on major theoretical and practical issues; to promote academic cross field exchange and integration, so as to achieve the universality of social science and the comprehensive and applicability of consulting services.

\section{ORGANIZATION SYSTEM}

As an important base for training high-level specialized talents, colleges and universities have the characteristics of multi-disciplinary and multi-level discipline structure. They are the main departments with the most intensive talents, the most powerful force, the most complete disciplines, the most research tasks and the most abundant departments. The social science association of colleges and universities "takes caring people's spiritual needs and promoting the development of social public welfare as its own responsibility, and plays a role of bridge and link in the social information transmission network. It is not only a bridge and link between the party and the government to contact the public, but also an important channel for the public to participate in social and national management."

Due to the specific organizational environment of colleges and universities, it is necessary to solve the problem of how to adapt to the existing organizational system environment of colleges and universities in the development process for social science associations in colleges and universities, including how to define the boundaries and responsibilities between the social science association of colleges and universities and scientific research management departments. On the premise of clear functional orientation, how to establish a set of management mechanism which is organically combined with the university management system, complementary to each other and free and independent is a problem worthy of high attention and active exploration. According to the practical experience of the joint transportation of social science associations in colleges and universities in and out of the province, the organization and management of the association should adhere to the following principles.

\section{A. Principle of Joint Integration}

According to the objective and subjective conditions, such as the tasks and objects of work, the quality and structure of social science workers, the advantages of disciplines and the setting of specialties, the association must build an academic platform for the social science workers in colleges and universities in activities of understanding the world, civilization inheritance, theories innovation, consult and educate people, and serving society, build a stage for experts and scholars to full play their talents, gather wisdom, integrate social science resources, give full play to the unique advantages of the association, effectively promote the association between social science experts and the government, and play the role of organization, communication, coordination, participation in decisionmaking among management departments, social science researchers and society. According to the social needs and the advantages of the university, experts and scholars are organized to actively participate in the research, academic discussion and tackling of key problems jointly; to break through the limitations of disciplines, actively organize cross field comprehensive research, and conduct in-depth

\section{B. Principle of Freedom and Autonomy}

The social science associations of colleges and universities should advocate the freedom in academic thought and exploration, and implement the principle of democratic management. In carrying out the academic activities of social sciences, the associations of colleges and universities should actively play the role of academic guidance and democracy, adhere to the policy of "a hundred flowers bloom, a hundred schools of thought contend", mobilize the enthusiasm and creativity of teachers and students in scientific research, and encourage exchanges and debates of different schools and academic views; unite social science workers in colleges and universities to create an academic atmosphere of seeking truth from facts, being brave in exploration and innovation, being democratic and loose. With the increasingly standardized management of the social science associations in colleges and universities, as an academic mass organization, the social science associations in colleges and universities should not only change and innovate their working concepts in the process of talent collection and integration, but also fully reflect the autonomy and initiative of the social science workers, highlight their academic rights and promote the rapid development of local economic and cultural construction with the breakthrough of individual scientific research and the overall promotion of scientific research force.

\section{Principle of Cooperation and Complementary}

As a mass organization of social science workers in colleges and universities, the social science association of colleges and universities does not have the institutionalized management power given by the university management system, but implements a bottom-up management mode. With the multi-dimensional development of the social structure, the social science associations in colleges and universities have gain more independence and autonomy in their development, and the role of the social science association of colleges and universities in college management will become increasingly important. Considering the characteristics of the two management modes of the social science association and the scientific research management department in colleges and universities, two equal cooperative relations and dialogue mechanisms of management are established, exchanging information with each other, carrying out multi-level and all-round cooperation, exercising management functions and promoting the development of the social science in colleges and universities jointly, which can effectively make up for their own shortcomings and maximize the management relationship between the association of social science and the scientific research management department, which is also the vitality of the association. benefits, so as to form the a harmonious symbiotic 
formed a set of development strategies of borrowing, dislocation and substitution, which is supported by the Party Committee and administrative authority, with all members of the university's social science association as the main body of activities, with the Secretariat of the University's Social Science Association as the guarantee of management and implementation, and coordinated with all management departments in the university, and gradually explored a set of development strategies in the work of the university's social science association practice.

1) Borrowing development, expanding the influence of the social science association: In the initial stage of its establishment, the N University Social Science Association and the University's Scientific Research Office jointly work to realize the development of loaned positions with the help of resources such as the scientific research office. With the help of the platform of the scientific research department, establish contact with various academic groups in the university and provide guidance and support, including the support of the activity site and the school news publicity. By using the platform of the Scientific Research Department and the Propaganda Department, the propaganda of the work of the social science association will be strengthened to provide propaganda support for all kinds of academic activities of social sciences in the university.

2) Dislocation development, building a new link between academic management and administrative management: The social science association is cross college, in a sense, it is also relatively grassroots, and it can transcend the restrictions of College interests and departmentalism to a certain extent. Therefore, through the members of the university's social science association and the academic committee, the academic committee of the school has formed a dislocation, which has laid the foundation for the development of the social science association itself.

3) Substitution development, building a home for social science workers: When cooperating with the administrative departments of the university, the social science association of the university not only pays attention to highlighting the name of the association of social science, but also does some work that the functional departments of the university have not carried out, including contacting various existing academic groups in the university, actively promoting the establishment of new loose academic groups, and organizing the academic salon activities of young teachers. In this process, the academic democratic atmosphere is formed, which increases the attraction of the activities of the Social Science Association and highlights the image of the family of social science workers.

\section{CONCLUSION}

Since 2015, it has been a golden period for the social science associations of colleges and universities in Jiangsu Province from the establishment to the rapid development. In this process, the social science circle of Jiangsu Province has
After nearly four years continuous development and practice, N University's Social Science Association has gradually 
Universities Think Tanks - Governments" [J]. Heilongjiang Researches on Higher Education, 2018(8):40-44. (in Chinese)

gradually formed a consensus that the establishment of the social science association in colleges and universities and the promotion of the connotation construction of the social science association in colleges and universities are the internal requirements for the prosperity and development of philosophy and social sciences and the construction of philosophy and social sciences with Chinese characteristics, which will help to play the role of bridge and button, promote the construction of disciplines, improve the academic atmosphere, and promote the cooperation among societies, disciplines and scholars, as well as the connection and exchange between natural science and social science, to realize cross-border union and coordination, to play a platform role, to organize academic activities to promote exchanges and collisions, to realize theoretical and academic innovation, to safeguard the rights and interests of philosophy and social science workers, and to lead the correct academic orientation.

In the future development, as a joint organization of philosophy and social science workers under the leadership of the Communist Party of China, N University Social Science Association needs to further accurately grasp the new tasks and requirements put forward by the development of the party and the state for philosophy and social science work, keep pace with the times, make clear the basic positioning, constantly enrich the development strategies of borrow, dislocation and substitution, strengthen organization management, and communicate with others through the practical performance of functions, the attraction, cohesion and combat effectiveness are constantly enhanced inside and outside the university, so as to achieve a promising position and improve the connotation construction of the social science association of colleges and universities to a new level.

\section{REFERENCES}

[1] Dong Suzhe. Inspiration from the Development of Think Tanks in the United States to the Construction of Think Tanks in Chinese Universities [J]. Creative Technology, 2018,v.18; No.220(6):42-44. (in Chinese)

[2] Li Ning. On the Basic Position of the Association of Social Science in the New Situation [J]. Youth and Society: (First part), 2014(9):255256. (in Chinese)

[3] Liu Hui, Li Hening. Three Aspects of University Think Tanks: Connotation, Challenge and Development Path [J]. Journal of Intelligence, 2018, 37(8):45-50. (in Chinese)

[4] Liu Shuangxi. An Analysis of the Path of Building a New Type of University Think Tank with Chinese Characteristics [J]. Heilongjiang Researches on Higher Education, 2017, No.284(12) :46-49. (in Chinese)

[5] Peng Zhengwen. The Function Orientation and Innovative Development Ideas of the Social Science Association of Colleges and Universities [C]. Proceedings of the 2008 Annual Symposium of Hunan Provincial Social Science Association, 2008. (in Chinese)

[6] Xu Yue. The Practical Dilemma and Development Strategy of the Construction of New University Think Tanks [J]. Contemporary Education Science, 2018(8):64-68. (in Chinese)

[7] Yue Hongjiang. Decision-Making Consultation on the Transformation of Social Science Achievements in Colleges and Universities: A Study on the Three Spiral Model of "Colleges-
[8] Zhu Zhen. On the Development of Think Tanks in Domestic University [J]. Inner Mongolia Science Technology and Economy, 2018, No.407(13):5-7. (in Chinese) 